\title{
Grupos de Pares / Peer Groups
}

https://doi.org/10.21814/uminho.ed.36.34

Caterina Satta

University of Cagliari, Italy 



\section{Grupos de Pares}

O conceito de grupos de pares, fundamental para os novos estudos sociais da infância, sublinha a importância dos pares no mundo social das crianças.

Trata-se de um conceito frequentemente utilizado na literatura para definir as culturas juvenis, nas quais a idade passa a ser um elemento distintivo de um grupo caracterizado dentro da ordem geracional pela adoção de estilos de vida, gostos, atitudes e comportamentos para se diferenciar da sociedade adulta. Em termos negativos, a influência social de outros jovens uma vez que estes constituem um importante ponto de referência durante os anos da adolescência - uma etapa durante a qual, muitas vezes, crianças e jovens se tornam alvo de uma ampla gama de medidas de controlo por parte dos adultos. Em contextos sociais específicos (por exemplo, a escola), a cultura do grupo de pares é um produto da estrutura social (a escola divide as crianças em anos diferentes com base na idade e usa a idade para marcar as divisões entre os grupos de alunos e grupos de professores), mas também é um espaço negociado no qual as crianças podem compartilhar suas próprias visões e perspetivas do mundo. Como mostrou Allison James (1993), o grupo de pares desempenha um papel significativo - enquanto grupo exigente - para a identidade das crianças em relação ao tamanho de seus corpos.

Os grupos de pares também são importantes em termos do processo de socialização, uma vez que a aprendizagem significativa sobre os elementos da sociedade - normas sociais, valores e papéis, por exemplo - ocorre no seu seio.

Brincar é uma característica essencial dos grupos de pares de crianças, visto que é entendida como uma característica principal e distintiva da atividade na infância (brincar é o que as crianças fazem, enquanto os adultos só brincam quando o propósito é brincar) e um meio de diferenciação dos adultos. Por meio da brincadeira, as crianças constroem as suas "culturas de pares" únicas, como afirmou William Corsaro, e não estão apenas experimentando o mundo social, mas estão contribuindo ativamente para a produção e mudança cultural. Este autor fala sobre o grupo de pares como uma "coorte ou grupo de crianças que passam tempo juntas diariamente" 
(Corsaro, 2005, p. 109) e sobre a cultura de pares como "um conjunto estável de atividades e rotinas, artefactos, valores e preocupações que as crianças produzem e compartilham na interação com os pares" (Corsaro, 2005, p. 131). As culturas de pares das crianças não são formadas em espaços exclusivamente constituídos por crianças, mas são produzidas e reproduzidas, nas famílias, nas escolas e também em relação aos meios de comunicação e aos brinquedos. Assim, na sua teoria da "reprodução interpretativa", Corsaro mostra que as crianças, por meio das suas interações, umas com as outras, não estão simplesmente aprendendo sobre a cultura, mas estão interpretando a cultura coletivamente e contribuindo para produzir culturas de pares específicas diferentes das dos adultos. Um processo de apropriação e de reprodução que pode trazer igualmente mudanças para a sociedade adulta em geral. $O$ autor demonstra que as crianças podem influenciar os adultos e não apenas ser afetadas pelos mesmos, tendo uma contribuição independente para a mudança social.

O mérito dessa visão é que rejeita os relatos tradicionais que retratam as crianças como recipientes meramente passivos de processos de socialização; pelo contrário, esta visão enquadra o desenvolvimento individual dentro da teia de processos coletivos de participação das crianças na reprodução e na mudança social.

Os grupos de pares também são baseados no género. 0 estudo de Thorne intitulado Gender Play. Girls and Boys in School (1993) revela uma ampla gama de diferentes configurações que os modelos de género assumem nas interações entre meninas e meninos numa escola primária. A sua pesquisa fornece um contraponto importante à abordagem do desenvolvimento, mostrando como as diferenças das crianças são o produto de processos relacionais que são construídos e moldados também por relações intrageracionais em curso. Este estudo continua a ser, ainda hoje, um dos poucos que indutivamente aborda, a nível micro, as relações de género entre pares, ao invés de apenas investigar a influência de pressupostos e restrições socioculturais na definição da aquisição de papéis de género pelas crianças.

Tal mudança, valorizando o papel dos pares e considerando as crianças como agentes ativos, chamou a atenção sobre como meninos e meninas coletivamente criam, recriam e às vezes desafiam a ordem e as normas de género.

Mesmo em estudos recentes sobre uma ideia de "boa parentalidade", as crianças são retratadas, dentro de uma visão determinística do processo 
de socialização (ou seja, os comportamentos inadequados ou desvios ou marginalidades das crianças são o efeito de uma criação inadequada pelos pais), como recipientes de boas práticas ou como espelhos de "bons pais". Nesta visão, a socialização ainda é algo feito às crianças e não um processo por elas vivenciado.

Ao contrário, os grupos de pares tornam-se contextos de socialização onde as crianças aprendem a dar sentido às normas e aos valores por meio dos quais a sua própria identidade e outras identidades são criadas. Apesar de ser muitas vezes considerado e representado pelos adultos como a fonte de maus comportamentos, quando visto do ponto de vista da criança, o grupo de pares pode ser uma rede de apoio e um ambiente de aprendizagem.

(Tradução de Marlene Schüssler D'Aroz)

\section{Peer Groups}

Central to the new social studies of childhood, the concept of peer groups underlines and emphasises the importance of peers in the social world of children. The concept is most commonly adopted in literature to define youth cultures in which age becomes a distinctive element of a group characterized - within the generational order - by the assumption of lifestyles, tastes, attitudes and behaviours through which young people differentiate themselves from adult society. In this sense, it can also be used to define, in negative terms, in negative terms, the social influence of other young people as a major point of reference for children and young people during the years of adolescence. As a consequence, peer groups have often become the target of a wide range of adult social control measures. In specific social contexts (e.g., the school), peer group culture is both a product of the social structure (school divides children into different age-based classes and uses age to mark the boundaries between the group of students and the group of teachers), but also a negotiated space in which children can share their own views and perspectives on the world. As Allison James has shown, peer groups play a significant role - as a demanding group - for children's identities in relation to their body sizes (1993).

Peer groups are also important in terms of the socialisation process, since significant learning about elements of society - social norms, values and roles, for examples - takes place in the context of the peer group. 
Play is an important feature of children's peer groups, given that it is seen as a primary and distinctive feature of children's activity (to play is what children do, while adults only play when there is a purpose to play) and a means of differentiation from adults. Through play, children build their unique "peer cultures", as William Corsaro stated, and they are not only experiencing the social world, but they are actively contributing to cultural production and change. He refers to peer groups as a "cohort or group of children who spend time together on an everyday basis" (2005, p. 109) and defines peer culture as "a stable set of activities or routines, artefacts, values, and concerns that children produce and share in interaction with peers" (p. 131). Children's peer cultures are not formed in spaces that are made up exclusively of children but are produced and reproduced in families, schools, and also in relation to the media and to toys. Thus, in his theory of "interpretive reproduction", Corsaro shows that children through their interactions with each other are not simply learning about culture, but they are collectively interpreting culture and contributing themselves to produce specific peer cultures different from those of adults. A process of appropriation and reproduction that can bring changes also into the wider adult society, demonstrates that children can influence adults, and not only be affected by them. Further, children are able to provide their own independent contribution to social change.

The merit of this view is that it rejects traditional accounts which depict children merely as passive recipients of processes of socialisation. On the contrary, it frames individual development within the web of collective processes of children's participation in social reproduction and change.

Peer groups are also based on gender. Thorne's study Gender Play. Girls and Boys in School (1993) reveals a wide range of different configurations that gender models assume in the interactions among girls and boys in a primary school. Her research provides an important counterpoint to developmental approaches, showing how children's differences are the product of relational processes that are built and shaped also by ongoing intra-generational relations. Her study remains today one of the few that inductively addresses, at the micro-level, gender relations between peers, rather than only investigating the influence of sociocultural assumptions and constraints in shaping children's acquisition of gender roles in early life.

Such a shift, giving value to the role of peers, and considering children as active agents, draws attention to how boys and girls collectively come to create, recreate, and sometimes challenge, gender order and norms. 
However, altough a peer groups centred approach is an alternative to traditional socialisation theory, the socialising process is still defined within an adultcentric frame as "a one-way transitive process". Thus, for example, even in recent studies on the "new parenting culture", children are depicted, within a deterministic view of the socialisation process (i.e. children's misbehaviours or deviancy or marginality are the effect of inadequate parenting), as recipients of good practices or as mirrors of "good parenting" while the focus is centered on the adult who educates in "a one-way transitive process". In this view, socialisation is still something done to children, not a process experienced by them.

On the contrary, what research within childhood studies showed, then, is that peer groups, peer groups become contexts for socialisation where children learn to make sense of the norms and values through which their own and other identities are created. While often regarded and represented by adults as the source of bad behaviour, from the child's standpoint, peer groups can be both a support network and a learning environment.

\section{Referências / References}

Corsaro, W. (2005). The Sociology of Childhood (2nd ed.). London: Sage.

James, A. (1993). Childhood Identities. Edinburgh: Edinburgh University Press.

Thorne B. (1993). Gender play. Girls and boys in school. Buckingham: Rutgers University Press. 